\title{
Review on E-Waste Management Strategies for Implementing Green Computing
}

\author{
Tamanna Akther Mukta \\ Dept. of Computer Science and Engineering \\ University of Chittagong \\ Chittagong, Bangladesh
}

\author{
lqbal Ahmed \\ Dept. of Computer Science and Engineering \\ University of Chittagong \\ Chittagong, Bangladesh
}

\begin{abstract}
Green computing is considered to the procedure of designing, manufacturing, using the products and managing them in a correct way to minimize the hazards from the environment. Ewaste has become an emerging concern in the whole environment. The utilization of e-waste has become a nonavoidable problem that the environment and ecology face. This paper focuses on the description of e-waste management for implementing green computing. This paper helps out the reader to get knowledge about e-waste management and green computing and how they can influence each other in the activation process. Therefore, E-waste management is working as an approach to green computing.
\end{abstract}

\section{General Terms}

E-Waste Management, Green Computing.

\section{Keywords}

Green Computing, E-Waste, Sustainability, Recyclability, Carbon Footprint, Energy Saving.

\section{INTRODUCTION}

Due to progress in the field of science and technology brought about the industrial revolt in the 18th Century which marked a new era in human civilization. In the 20th Century, the information and communication revolution has brought huge changes in the way our lives are organized, economies, industries, and institutions [1]. The tremendous technological development in the $21 \mathrm{st}$ century has many advantages. However, the growth of the technologies demands high energy accompanied by intention e-waste and hazards emissions. As technology is increasing exponentially contribute towards more global warming and climate change. For these facts, the world is giving more attention to green computing and e-waste management [2].

Nowadays the most exciting areas focus on greening things such as green communication and networking, green design and implementation, green services and applications [3]. Green Computing can be referred to as the optimal utilization of information technology for governing the sustainability attainment of an organization [4].

Green computing could be a well-balanced and sustainable approach towards the achievement of a greener, healthier and safer environment without compromising the technological needs of the present and future generations. How can the ground demand of technology can be satisfied without putting any pressure on the environment? The main goal of green computing is to maximize energy efficiency during the product lifetime. In this section, a brief discussion is based on green computing and e-waste management. This is followed by a section of discussion of related research in the field of implementing green computing.
Electric waste(e-waste) is when electronic products have come towards the end of their "useful life." E-waste is one of the fastest-growing waste streams in the world. In developed countries, it, on average, equals $1 \%$ of the total solid waste. The increasing "market penetration" in developing countries, "replacement market" in developed countries and "high obsolescence rate", make e-waste one among fastest waste streams [5]. It must be ensured that natural resources and the environment are needed to conserve and available for our next generation to live. By recycling raw materials from discarded electronics, natural resources are conserved and air and water pollution caused by hazardous disposal are avoided [6]. Recycling computing equipment can keep harmful materials such as lead, mercury out of landfills. Reuse can happen in several ways. It might take stock of old equipment [7].

Environmental Sustainability involves effort like monitoring the state of the physical world, managing the direct and indirect impacts of large-scale human enterprises like agriculture, transport and manufacturing and informing individuals' personal choices in consumption and behavior [8]. At present, the condition of e-waste management is at a very poor stage. By contributing to e-waste management, the world will turn out greener and eco-friendlier.

The study gives details about how e-waste management can help green computing, what steps are involved in e-waste management and how much it will be effective to works ewaste management as an approach for green computing.

The background studies and some existing works on green computing are presented in the upcoming section 2 and section 3. Then the review analysis is described in section 4 . After that, section 5 includes the optimal solutions of E-Waste Management for implementing Green Computing and finally, the paper has concluded with the scope of future work in section 6 .

\section{BACKGROUND STUDIES}

\subsection{Green Computing}

The ever-increasing growth of technology caused an increase in necessary facilities and structure to maintain it. We are living in the age of a tremendous increase in information and necessary infrastructure and equipment which generate, process, store and use the same [9]. Green computing is often defined as the efficient use of computing resources. It's the name attached to the movement which represents an environmentally responsible way of computing through reduced power consumption.[5].

Green Computing represents a responsible way to address the problem of global warming. By adopting green computing human can contribute positively to environmental sustainability and protect the environment while also reduce energy and paper cost. The concept of green computing was 
originated in 1992 by U.S. Environment Protection Agency by launching an Energy Star rating in monitors and other electronic equipment $[10,11,12]$ Green computing is started in the 90's when the US environment protection energy launched the Energy Star Program.

Green computing essentially includes four key areas illustrated in Figure 1 and explained as follows [10, 13, 14, $15]$

- Green Use: Using resources in an environmentally sound manner while reducing their energy

- Green Design: Designing energy-efficient and environmentally sound objects and services.

- Green Disposal: Recycling e-waste with minimal or no impact on the environment.

- Green Production: Manufacturing electronic devices with minimal impact or no impact on the environment.

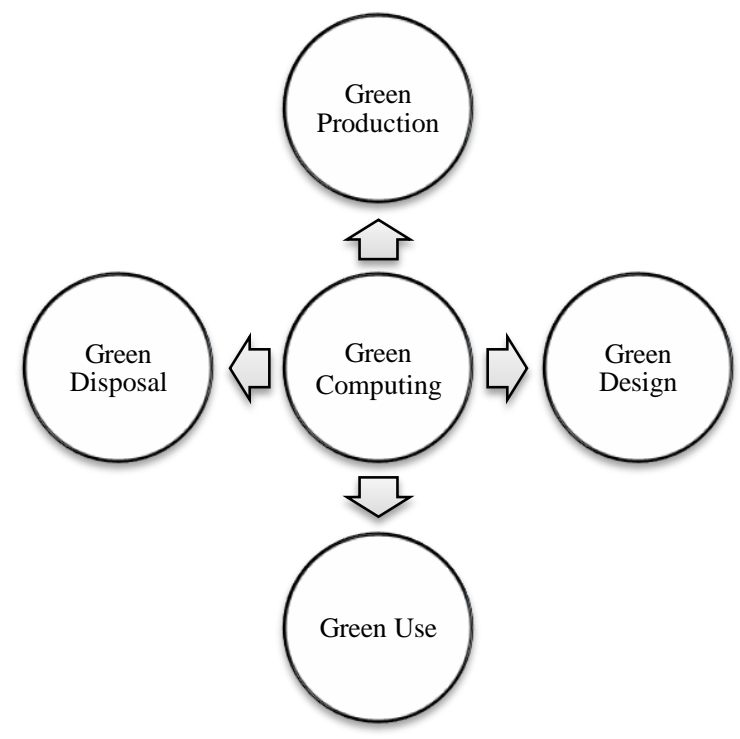

Figure 1: Key Components of Green Computing

The major causes of Green computing are [6, 11]: -

- A lot of electricity is used: Most of the natural resources are being used to get electricity that all have some impact on the environment.

- Creates more toxic waste: Our computers are updated, throwing out outdated computer resources, peripherals and other hardware devices, etc., these are the hazardless toxic waste we are producing that really damaging the environment nowadays.

Figure 2 illustrates the approaches that must be followed step by step to implement green computing $[10,16]$.

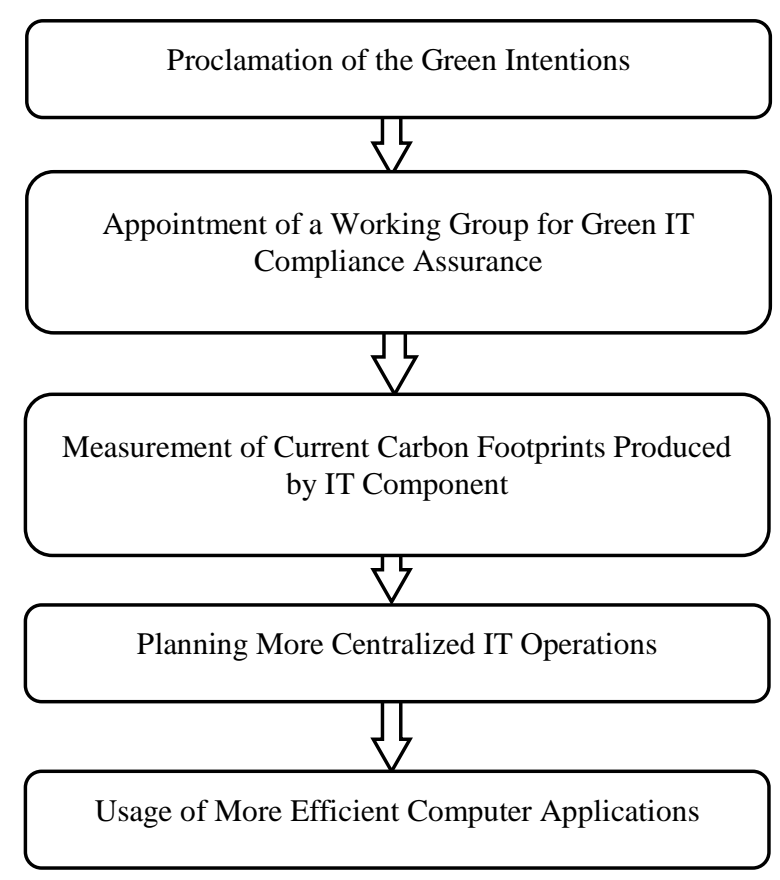

Figure 2: The Approaches Towards Green Computing.

\subsection{E-Waste Management}

Any substance that's discarded is identified as waste. It is a valuable raw material located in the wrong place. Many of the wastes, at the present utilized in an uneconomic manner or left completely un-utilized, are causing great hazards to the human environment [5]. E-waste is a popular name for electronic products nearing the end of their "useful life. "Examples of e-waste are computers, televisions, VCRs, stereos, copiers, and fax machines [17].

The reasons why e-waste is a problem are given below-

- Electronic waste keeps growing and growing

- Environmental effects of e-waste

- Tons e-waste is shipped overseas

- Health implications of electronic waste

- Electronic waste and data security

The planet generates about 40 million plenty of PCs, cathoderay tube (CRT) screens, fax machines, game consoles, mobile phones, and other e-waste each year [18]. In 2017, the quantity of e-waste is approximately 72 billion tons worldwide. The USA is the largest producer of e-waste in the world [19]. Today, many countries recycle their e-waste but due to the selfishness of mankind and lack of proper knowledge in the recycling of e-waste, many of these countries had performed the recycle process in an informal or illegal way [20]. By adopting green policies and respecting rules and regulations, with each party committed to promoting greenness, there will be an amelioration of the situation [21].

The life cycle of e-waste can be divided into four phases [22]:

- Phase I - Production of EEE (Electrical and Electronic Equipment).

- $\quad$ Phase II - Generation of UEEE (Used Electronic and Electrical Equipment).

- $\quad$ Phase III - Decision for Fate.

- $\quad$ Phase IV - E-Waste Processing 
The most common materials are found in electrical and electronic equipment's Iron and Steel and Plastic are the second largest component presents in electronic waste materials. Depending on the chemical composition of e-waste, it can be used as a coarse aggregate, fine aggregate, fine filler in concrete [23].

Table 1 presents the physical properties of E-waste examined by different researchers.

Table 1. Physical Properties of E-Waste, Adopted from [23]

\begin{tabular}{|c|c|c|c|c|}
\hline Properties & 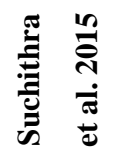 & 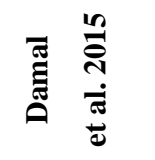 & 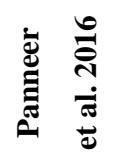 & 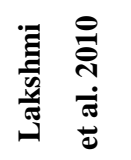 \\
\hline $\begin{array}{l}\text { Specific } \\
\text { Gravity }\end{array}$ & 1.9 & 1.2 & 1.44 & 1.01 \\
\hline $\begin{array}{c}\text { Water } \\
\text { Absorption } \\
(\%)\end{array}$ & 0.2 & $<0.2$ & Nil & $<0.2$ \\
\hline Color & $\begin{array}{c}\text { Dark and } \\
\text { Ivory }\end{array}$ & $\begin{array}{c}\text { Brown } \\
\text { and } \\
\text { Dark }\end{array}$ & $\begin{array}{c}\text { Dark and } \\
\text { Brown }\end{array}$ & $\begin{array}{l}\text { White } \\
\text { and Dark }\end{array}$ \\
\hline Shape & Angular & $\begin{array}{c}\text { Round } \\
\text { and } \\
\text { cylindrical }\end{array}$ & Angular & Angular \\
\hline $\begin{array}{l}\text { Crushing } \\
\text { Value (\%) }\end{array}$ & - & $<2 \%$ & - & $<2 \%$ \\
\hline $\begin{array}{c}\text { Impact } \\
\text { Value }(\%)\end{array}$ & - & $<2 \%$ & - & $<2 \%$ \\
\hline
\end{tabular}

Table 2 presents the pollutant and their occurrences in waste produced by electrical and electronic equipment [1].

Table 2. Pollutants of E-Waste, Adopted from [1]

\begin{tabular}{|c|c|}
\hline Pollutant & Occurrence \\
\hline Arsenic & $\begin{array}{c}\text { Semiconductors, Diodes, Microwaves, } \\
\text { LEDs (Light-emitting diodes), Solar Cells }\end{array}$ \\
\hline Barium & $\begin{array}{c}\text { Electron Tubes, Filler for Plastic and } \\
\text { Rubber, and Lubricant Additives }\end{array}$ \\
\hline $\begin{array}{c}\text { Frominated } \\
\text { Agent }\end{array}$ & $\begin{array}{c}\text { Casing, Circuit Boards (Plastic), Cables, } \\
\text { and PVC Cables }\end{array}$ \\
\hline $\begin{array}{c}\text { Cadmium } \\
\text { Chrome }\end{array}$ & $\begin{array}{c}\text { Batteries, Pigments, Solder, Alloys, } \\
\text { Monitor Cathode-ray Tubes (CRTs) }\end{array}$ \\
\hline Cobalt & Dyes/Pigments, Switches, Solar \\
\hline Copper & $\begin{array}{c}\text { Insulators } \\
\text { Conduls, Circuitry, Pigments }\end{array}$ \\
\hline Lead & $\begin{array}{c}\text { Lead Rechargeable Batteries, Solar, } \\
\text { Transistors, Lithium Batteries, PVC }\end{array}$ \\
\hline
\end{tabular}

\begin{tabular}{|c|c|}
\hline Pollutant & Occurrence \\
\hline & $\begin{array}{c}\text { (Polyvinyl Chloride) Stabilizers, Lasers, } \\
\text { LEDs, Thermoelectric Elements, Circuit } \\
\text { Boards }\end{array}$ \\
\hline Liquid Crystal & Displays \\
\hline Lithium & $\begin{array}{c}\text { Mobile Telephones, Photographic } \\
\text { Equipment, Video Equipment (Batteries) }\end{array}$ \\
\hline Mercury & $\begin{array}{l}\text { Components in Copper Machines and } \\
\text { Steam Irons; Batteries in Clocks and } \\
\text { Pocket Calculators, Switches, LCDs }\end{array}$ \\
\hline Nickel & $\begin{array}{l}\text { Alloys, Batteries, Relays, } \\
\text { Semiconductors, Pigments }\end{array}$ \\
\hline $\begin{array}{c}\text { PCBs } \\
\text { (Polychlorinated } \\
\text { Biphenyls) }\end{array}$ & $\begin{array}{l}\text { Transformers, Capacitors, Softening } \\
\text { Agents for Paint, Glue, Plastic }\end{array}$ \\
\hline Selenium & $\begin{array}{l}\text { Photoelectric Cells, Pigments, } \\
\text { Photocopiers, Fax Machines }\end{array}$ \\
\hline Silver & $\begin{array}{c}\text { Capacitors, Switches (Contacts), } \\
\text { Batteries, Resistors }\end{array}$ \\
\hline Zinc & $\begin{array}{c}\text { Steel, Brass, Alloys, Disposable and } \\
\text { Rechargeable Batteries, Luminous } \\
\text { Substances }\end{array}$ \\
\hline
\end{tabular}

Here is the description of how designers plan to make future computer more eco-friendly across its entire life span, from manufacture to recycling [24]:

- Energy-intensive manufacturing of computer parts can be minimized by making the manufacturing process more energy efficient.

- By replacing petroleum-filled plastic with bioplastics - plant-based polymers - which require less oil and energy to supply as compared to traditional plastics with a challenge to keep these bio-plastic computers cool in order that electronics won't melt them.

- Landfills can be controlled by making the best use of the device, by upgrading and repairing in time. Making up-gradation and repairing processes.

- Easier and cheaper and avoiding discarding won't only control e-waste out of dumps but also save energy and materials needed for designing and producing an entire new computer.

- High power consuming display devices are often replaced with green light displays made from OLEDs, or organic light-emitting diodes, etc.

- The use of toxic materials like lead can be replaced by silver and copper that makes recycling expensive and time-consuming. The process is made simpler by recycling computer parts separately with an option of reuse or recycle.

E-waste is not pollution, nor is it waste - it's a vital resource that are only just starting to value in full [25]. 


\section{EXISTING WORKS}

Green Computing has become an important topic in these recent days. Several works have been carried out with different approaches in this field.

S. Mmeah [26] reviewed the current literature on green computing and its influences on sustainable IT services with the idea of identifying a core set of principles to guide sustainable IT service design and leverage points to improve customer value, business value, and societal value.

Wu-chun Feng [27] discussed how power and cooling issues in supercomputing have evolved from a secondary concern to a primary design constraint. Joseph Williams [28] addressed the aspect of green computing that reflects the architectural approach and described what constructing that architectural view will require.

S. Murugesan [29] showed the power of IT in innovative ways to address mounting environmental issues and make IT systems and their use greener. He presented a holistic approach to greening IT and highlighted how IT could help businesses in their environmental initiatives and reduce their carbon emissions.

B. Anthony Jnr. [4] collected through data from 133 respondents in industries that currently operate their in-house data centers and used the information to verify the Green computing life cycle strategies. He also discussed the Green computing life cycle strategies to be applied for Greening data centers in IT-based industries.

K. Suryawanshia [30] discovered the most important barrier for the successful implementation of Green ICT by using the SPSS tool and Wilcoxon Test. It assists the policymaker in designing green strategies and policies based on barriers. The paper pertained Green ICT and sustainable development together and 10 barriers were summarized.

C. Pattinson [31] analyzed the current state of "ICT Sustainability" as a subject in the curriculum, and showed that the subject deserves greater coverage, and for that coverage to be more "upfront" than it currently is.

S. Agarwal [2] presented a systematic study on the issues of climate change explained green computing from the business and IT perspective by exploring, and also to find the best practices of green computing into the users of ICT.

Z. Gandomi [32] showed that to make data centers as green is a major concern for data admins although having limited knowledge about energy-efficient methods. He presented a comprehensive questionnaire survey on the application of green metrics and knowledge about green metrics of data admins and designed a Green Data Center Tools to monitor the PUE and DCIE, also calculate power consumption, energy cost, and carbon footprint.

G. Hatzivasilis [33] proposed the CE-IoT framework that materializes the $\mathrm{CE}$ business model and the integration with the IoT infrastructure which is quite generic and applicable in various CE-IoT settings. Decision Support Systems (DSS) are parsed with the outcome that represented the organization's administration strategy.

J. Ghorpade-Aher [34] proposed an approach named Crowd Computing that describes the importance of new emerging technology and provide cost-saving benefits and ease of use for the ultimate user. He also explained the importance of ES (Estimated Energy Saving) and Ps (Power Saving) by handling the resources efficiently.
S. Agarwal [35] presented all the references based on Desktop Virtualization which are related to host-based forms of desktop virtualization that the client doesn't need any processor, memory and storage facilities. The proposed solution can be implemented in both LAN and WAN environments where the bandwidth and speed became an important driving factor.

B. Saha [36] provided a survey of several important works of literature based on the field of green computing that emphasizes the importance of green computing for sustainable development.

Qayoom [37] proposed green cloud computing (GCC) approach which aims to reduce the carbon footprint of data centers by reducing their energy consumption. He also discussed various facts and challenges faced in the Green IT environment this research and a survey is also done to be followed in data centers for improving energy efficiency.

I. Ahmed [38] presented a survey on different basic SLA parameters for various services in ICT industries which focused on finding the gaps and incorporating basic SLA parameters with existing green computing issues and ethical issues for various services in various computing domains. He also defined future GSLA in relationship with ICT product life and three pillars of sustainability.

V. P. Parmer [39] explained the way to optimize computing power and minimize electricity usage as well as wastage and minimize the effect in the environment.

A. Woodruff [40] represented a qualitative study of "green" individuals in the United States who have made significant accommodations to their homes and lifestyles in order to be more environmentally responsible. $\mathrm{He}$ described the motivations, practices, and experiences of committed green individuals and used the findings to inform the space of potential ideals.

S. Singh [7] explained the major issue of green computing \& how it can benefit the world as well as the Environment. He examined significant architectural decision points in the infrastructure and discusses discuss holistic issues for environmental sustainability.

S. D. Meena [41] proposed two major solutions to Green ITVirtualization and Docker. She also presented some notable solutions such as Server Consolidation and some of the noteworthy Green Computing practices.

R. Bala [42] proposed a new power-saving algorithm that works for reducing the heat generated by the datacenters in the IT industry. The main goal of the proposed algorithm is to reduce the power consumption by data centers and reduce the Carbon footprints as well as provide the maximum savings to the client and the provider.

P. Ranbhise [9] stated a model that can be adapted to implement a comprehensive green strategy within small businesses. He defined the problems in different areas and presents with recent approaches to overcoming the same.

Laura-Diana Radu [43] contributed towards the identification of specific determinants of the adoption of green ICT in organizations to research on green ICT and provided an overview of the current research on the overall and specific determinants that influence the adoption of green ICT in organizations.

M. Salam [44] identified and scrutinized a list of critical success factors (CSFs) for vendors in the development of 
green and sustainable software and a list of 20 success factors through the SLR process. He proposed that the identified CSFs may lead vendors towards the development of green and sustainable software.

\section{REVIEW ANALYSIS}

In the last few years, the electrical waste industry has tremendous growth. Electronic device is widely used through our daily life from organizations to home [39]. The everincreasing waste contains complex characteristics and they also need a set of efficient technology and process to manage it [13]. Due to the absence of any proper disposal systems, waste has become a burden on our environment [5]. Given the volume of e-waste being generated and the content of both toxic and valuable materials in them, e-waste is also emerging as a business opportunity of increasing significance [1].

Several works have done in the field of e-waste management that presented different technologies and methods which really proved that electrical waste has potential advantages towards green computing if it is managed properly.

Table 3 represents the analysis that shows several methods or technologies are used in existing work.

Table 3. Analysis of E-Waste Management Related Works

\begin{tabular}{|c|c|}
\hline Authors & Tools or Methods Used \\
\hline $\begin{array}{l}\text { A. Anam, and A. } \\
\text { Sayed [46] }\end{array}$ & $\begin{array}{l}\text { Designing energy-efficient } \\
\text { computing devices, } \\
\text { reducing the use of dangerous } \\
\text { materials and encouraging } \\
\text { the recyclability of digital devices } \\
\text { and paper. }\end{array}$ \\
\hline $\begin{array}{l}\text { B. Debnath, R. } \\
\text { Kundu, R. Baidya, } \\
\text { and S. K. Ghosh [47] }\end{array}$ & $\begin{array}{l}\text { Quality Function Deployment } \\
\text { (QFD) analytical tool is proposed to } \\
\text { find different parameters from } \\
\text { primary research data that affect the } \\
\text { e-waste recycling practice as a } \\
\text { green computing approach. }\end{array}$ \\
\hline B. Saha [48] & $\begin{array}{l}\text { Reusability or recyclability and } \\
\text { biodegradability of used products } \\
\text { and wastes. Reduction in the use of } \\
\text { hazardous materials, minimizing } \\
\text { energy consumption while } \\
\text { maximizing output from the product } \\
\text { during its lifetime. }\end{array}$ \\
\hline B. H. Robinson [49] & $\begin{array}{l}\text { Standard remediation technologies } \\
\text { such as Disassembly and } \\
\text { Destruction of the equipment, } \\
\text { Mechanical separation, Pyro- hydro- } \\
\text { and Bio-metallurgical processes, } \\
\text { Pyrometallurgical process, Shoddy } \\
\text { operations, etc. }\end{array}$ \\
\hline $\begin{array}{l}\text { D. Tiwari, and N. G. } \\
\text { Dhawan [1] }\end{array}$ & $\begin{array}{l}\text { Develop a time-series multiple } \\
\text { lifespan end-of-life model }\end{array}$ \\
\hline $\begin{array}{l}\text { L. Jian, and Z. } \\
\text { Shanshan [50] }\end{array}$ & $\begin{array}{l}\text { Implement ERP Systems that } \\
\text { standardize the market of electronic } \\
\text { product recycling. }\end{array}$ \\
\hline
\end{tabular}

\begin{tabular}{|c|c|}
\hline Authors & Tools or Methods Used \\
\hline $\begin{array}{l}\text { Md. Masuduzzaman, } \\
\text { S. K. S. Amit, and } \\
\text { Md. Alauddin [23] }\end{array}$ & $\begin{array}{c}\text { Recycle of e-waste aggregate in } \\
\text { concrete to increase the potential } \\
\text { use as well as environmental } \\
\text { impact. }\end{array}$ \\
\hline $\begin{array}{l}\text { Mr.N.P.Jadhav, Mr. } \\
\text { R.S. Kamble, and } \\
\text { Mr.S.V.Kamble [51] }\end{array}$ & $\begin{array}{l}\text { Recycle the e-waste, keep and } \\
\text { upgrade it. Design such electronic } \\
\text { device which can be powered with } \\
\text { low power obtained from non- } \\
\text { conventional energy sources. }\end{array}$ \\
\hline $\begin{array}{c}\text { N. Mangaonkar, P. } \\
\text { Sabhani, and S. Sirsat } \\
{[52]}\end{array}$ & $\begin{array}{l}\text { Finding out the main source of e- } \\
\text { waste with the help of GIS. }\end{array}$ \\
\hline $\begin{array}{l}\text { P. Jayarajan, } \\
\text { S.Thenmozhi, } \\
\text { R.Maheswar, } \\
\text { S.Malathy and } \\
\text { R.Udaiyakumar [45] }\end{array}$ & $\begin{array}{l}\text { A monitoring system is proposed } \\
\text { for e-waste dump yards through an } \\
\text { electric device. }\end{array}$ \\
\hline $\begin{array}{l}\text { S.Vijaykumar, K. } \\
\text { S.Rajkarthick and } \\
\text { P.Karthik [53] }\end{array}$ & $\begin{array}{c}\text { E-waste can be degraded using the } \\
\text { gram-negative bacteria } \\
\text { pseudomonas and species like } \\
\text { Aspergillus Glaucus. }\end{array}$ \\
\hline $\begin{array}{c}\text { S. Khan, A. R. } \\
\text { Honnutagi, and Md. S. } \\
\text { A. Khan [54] }\end{array}$ & $\begin{array}{l}\text { The Interpretive Structural } \\
\text { Modeling (ISM) methodology is } \\
\text { used to evolve mutual relationships } \\
\text { among the factors that are used in e- } \\
\text { waste management. }\end{array}$ \\
\hline $\begin{array}{l}\text { S. Anawara, M. } \\
\text { Ghaffarb, F. Razzaqc, } \\
\text { and B. Bibi [55] }\end{array}$ & $\begin{array}{l}\text { Reduce e-waste using virtualization, } \\
\text { the functionality of Virtualization } \\
\text { and its contribution as an essential } \\
\text { feature in Green Computing }\end{array}$ \\
\hline $\begin{array}{l}\text { S. Th. Tsitomeneas, } \\
\text { A. I. Kokkosis, and A. } \\
\text { G. Charitopoulos [56] }\end{array}$ & $\begin{array}{l}\text { E-waste legislating, design and } \\
\text { management is proposed which } \\
\text { involves various principles, } \\
\text { theories, and practices. }\end{array}$ \\
\hline
\end{tabular}

All these methods and tools initially need the factors like-new technology, knowledge, awareness, and investment. All the approaches of E-waste management must be-

- Eco-Friendly.

- $\quad$ Cost-Effective.

- $\quad$ Energy Saving.

- Reduced $\mathrm{CO}_{2}$ Emission

- Independent of Technologies

Table 4 shows the comparative studies of these methods mentioned above based on these characteristics. 
Table 4. Comparison of E-waste Management Methods

\begin{tabular}{|c|c|c|c|c|c|c|}
\hline Type & Name of Method & 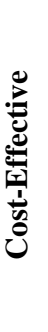 & 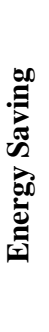 & 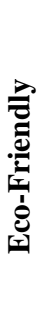 & 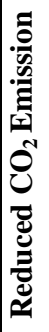 & 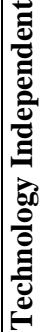 \\
\hline \multirow{6}{*}{$\begin{array}{c}\text { Green } \\
\text { Disposal }\end{array}$} & Aggregation & $x$ & $\checkmark$ & $\checkmark$ & $\checkmark$ & $x$ \\
\hline & Bio Degradation & $x$ & $\checkmark$ & $\checkmark$ & $\checkmark$ & $x$ \\
\hline & $\begin{array}{c}\text { Degradation Using } \\
\text { Gram Negative Bacteria }\end{array}$ & $\checkmark$ & $\checkmark$ & $\checkmark$ & $\checkmark$ & $\checkmark$ \\
\hline & Upgradation & $x$ & $\checkmark$ & $\checkmark$ & $\checkmark$ & $x$ \\
\hline & $\begin{array}{c}\text { ERP System } \\
\text { Implementation }\end{array}$ & $x$ & $x$ & $x$ & $x$ & $\checkmark$ \\
\hline & Legislation & $\checkmark$ & $x$ & $\checkmark$ & $x$ & $x$ \\
\hline \multirow{4}{*}{$\begin{array}{l}\text { Green } \\
\text { Production }\end{array}$} & $\begin{array}{c}\text { Interpretive Structure } \\
\text { Modelling }\end{array}$ & $x$ & $x$ & $\checkmark$ & $x$ & $\checkmark$ \\
\hline & Monitoring System & $x$ & $x$ & $\checkmark$ & $\checkmark$ & $x$ \\
\hline & $\begin{array}{l}\text { Quality Function } \\
\text { Deployment }\end{array}$ & $x$ & $\checkmark$ & $\checkmark$ & $x$ & $x$ \\
\hline & $\begin{array}{c}\text { Standard Remediation } \\
\text { Technology }\end{array}$ & $x$ & $\checkmark$ & $\checkmark$ & $x$ & $x$ \\
\hline \multirow[b]{2}{*}{ Green Use } & Virtualization & $x$ & $x$ & $\checkmark$ & $\checkmark$ & $x$ \\
\hline & $\begin{array}{c}\text { Reduction of Hazard } \\
\text { Material }\end{array}$ & $\checkmark$ & $\checkmark$ & $\checkmark$ & $\checkmark$ & $x$ \\
\hline \multirow{3}{*}{$\begin{array}{l}\text { Green } \\
\text { Design }\end{array}$} & $\begin{array}{c}\text { Energy Efficient } \\
\text { Computing Device }\end{array}$ & $x$ & $\checkmark$ & $\checkmark$ & $\checkmark$ & $x$ \\
\hline & $\begin{array}{c}\text { Time Series Multiple } \\
\text { Lifespan }\end{array}$ & $x$ & $\checkmark$ & $\checkmark$ & $\checkmark$ & $x$ \\
\hline & $\begin{array}{l}\text { Non-Conventional } \\
\text { Energy Supported } \\
\text { Device }\end{array}$ & $x$ & $\checkmark$ & $\checkmark$ & $x$ & $x$ \\
\hline
\end{tabular}

\section{PROPOSED SOLUTIONS}

For a developing society like ours, reduced use of electronics equipment being not a feasible option, we, therefore, need to emphasize reuse and recycling processes [5]. Eco-friendly approaches must be reached to contribute to a greener environment. Recycling falls within the green disposal category of green computing. This is one of the most efficient ways to combat the e-waste problem. Also, recycling helps in bringing down the greenhouse emissions caused by the manufacturing of latest products. The whole idea of recycling, refurbishing, and repair is relying on the pillar of green computing that teaches us to reuse our already used laptops, computers, and other gadgets $[12,57]$.

After analyzing all the methods of E-Waste Management and categorizing them into four key components and find out optimal solutions for each component based on five factors. If all these proposed methods are implemented, then we will contribute towards Green Computing successfully.
Here Table 5 shows the optimal solutions for every Green Computing Components.

Table 5. Proposed Optimal Solutions

\begin{tabular}{|c|c|}
\hline $\begin{array}{c}\text { Green Computing } \\
\text { Components }\end{array}$ & Optimal Solution \\
\hline Green Disposal & $\begin{array}{c}\text { Degradation Using Gram } \\
\text { Negative Bacteria }\end{array}$ \\
\hline Green Use & $\begin{array}{c}\text { Reduction Use of Hazard } \\
\text { Material }\end{array}$ \\
\hline Green Production & $\begin{array}{c}\text { Quality Function } \\
\text { Deployment }\end{array}$ \\
\hline Green Design & $\begin{array}{c}\text { Time-Series Multiple } \\
\text { Lifespan }\end{array}$ \\
\hline
\end{tabular}

\section{CONCLUSIONS}

Green computing aims to reduce the garbage and harmful effect of e-waste from our environment. The main goal of ewaste management is to keep society and the environment as a worthy place for living. As there are hinderance and challenges that we face while working with green computing and e-waste together. But the ever-increasing technology has made it easier to work in the field of green computing and ewaste management. All the organizations, companies must take e-waste management as a compulsory for making green computing as an initiative. Otherwise, the world will have to face several problems. It is hoped that there will be a lot of progress that must have done in this field. Research work could concentrate based on virtualization, cloud computing, and carbon footprint. That can be considered as future scope to develop in this field.

\section{ACKNOWLEDGMENTS}

I am thankful to my supervisor Dr. Iqbal Ahmed, Associate Professor of the University of Chittagong for critically reading the manuscript and giving the direction to modify it. I am also grateful to all of my teachers of my CSE department.

\section{REFERENCES}

[1] Dharna, T., and Nidhi G. D. 2014. E-waste Management: An Emerging Challenge to Manage and Recover Valuable Resources. International Journal of Environmental Research and Development. vol. 4. pp. 253-260.

[2] Shalabh, A., and Asoke, N. 2011. Green Computing - a new Horizon of Energy Efficiency and Electronic waste minimization: a Global Perspective. International Conference on Communication Systems and Network Technologies. 978-0-7695-4437-3/11.

[3] Alsamhi, S. H., Ou, M., M. S. Ansari, and Qingliang, M. 2018. Greening Internet of Things for Smart Everythings with A GreenEnvironment Life: A Survey and Future Prospects.

[4] Bokolo, A. Jnr., Mazlina, A. M., and Awanis, R. 2018 A Descriptive Study towards Green Computing Practice Application for Data Centers in IT-Based Industries. MATEC Web of Conferences 150, 05048.

[5] Chrisantus, O. 2020. The Impact of Managing Electronic Waste to Ensure Green Computing.

[6] United Nations Climate Change. 2020. E-waste From 
Toxic to Green India.

[7] Shivam, S. 2015. Green Computing Strategies \& Challenges. 978-1-4673-7910-6/15.

[8] Allison, W., and Jennifer, M. 2009. Environmental Sustainability. IEEE CS. 1536-1268/09.

[9] Prajyot, R. 2014. Green Computing: A way towards environmentally sustainable future. 978-1-4799-6629$5 / 14$.

[10] Matthew N. O. S., Nana, K. A., and Sarhan M. M. 2018. Green Computing: A Primer. Journal of Scientific and Engineering Research.

[11] Mavinder, S., and Anup, S. S. 2016. Green Computing. vol. 7. ISSN. 0976-5697.

[12] Team Veracity. 2019. E-Waste Recycling: An Approach Towards Green Computing.

[13] Rajeev, S., and Dinesh, S. 2015. Factors Affecting eWaste Management: An Interpretive Structural Modeling Approach. Fifth International Conference on Communication Systems and Network Technologies. 978-1-4799-1797-6/15.

[14] Office of Sustainability. 2020. Green Computing and EWaste.

[15] Youth Ki Awaaz in Environment. 2010. Green Computing- A New Horizon of Energy Efficiency and EWaste Minimization.

[16] Arundhati, K. 2018. Green Computing: A Solution to E-Pollution.

[17] Frea. 2011. Green Computing: Benefits of Green Computing.

[18] Jan, K. 2008. Recycling e-Waste: The Sky Is the Limit. IEEE Computer Society. ISSN. 1520-9209/08.

[19] S. M. Rezaul, K., Shariful, I. S., and Md. Anisur, R. A. 2018. Negative Impact and Probable Management Policy of E-Waste in Bangladesh.

[20] Lim, F. C., and Haw, W.Y. 2011. E-Waste Management: Are we ready for it?. Proceedings of the 5th International Conference on IT \& Multimedia at UNITEN. 978-14577-0989-0/11.

[21] Julius, T. N., and Mike, B. 2010. Is Green IT an Antidote to E-Waste Problems?. vol. 9. ISSN. 1473-7507.

[22] Biswajit, D., Reshma, R., and Sadhan, K. G. 2015. EWaste Management - A Potential Route to Green Computing. International Conference on Solid Waste Managemen.

[23] Md. Masud, U., Shishir, K. S. A., and Md. Alauddin. 2018. Utilization of E-waste in Concrete and its Environmental Impact - A Review

[24] Ranjita, P. 2013. E-waste Management: A Step towards Green Computing. International Journal of Environmental Engineering and Management. ISSN. 2231-1319. Vol. 4. pp. 417-424.

[25] Guy, R., and Houlin, Z. H . 2019. The world's e-waste is a huge problem. It's also a golden opportunity.

[26] Shedrack, M., Barida, B., and Abasiama, G. A. 2018. Assessing the Influence of Green Computing Practices on Sustainable IT Services. International Journal of Computer Applications Technology and Research. vo. 7. Issue. 10. pp. 390-397. ISSN. 2319-8656.

[27] Xizhou, F., Rong, G., and Wu-Chun. F. 2008. Green Supercomputing Comes of Age. vol. 10. pp. 17-23.

[28] Joseph, W., and Lewis, Curtis. 2008. Green: The New Computing Coat of Arms?. IEEE Computer Society. ISSN. 1520 9202/08.

[29] San, M., and G. R. Gangadharan. 2012. Green IT: An Overview. John Wiley \& Sons, Ltd.

[30] Kavita, S., and Sameer, N. 2015. Green ICT for Sustainable Development: A Higher Education Perspective. Procedia Computer Science 70. pp. 701 707.

[31] Colin, P. 2017. ICT and Green Sustainability Research and Teaching. IFAC PapersOnLine 50-1. pp. 129381294.

[32] Zohreh, G., and Salmiah, B. A. 2014. Towards Green Computing Application for Measuring the Sustainability of Data Centers: an Analytical Survey. Proceedings of the International Conference on Electrical, Electronics, Computer Engineering, and their Applications. ISBN. 978-1-941968-024.

[33] George, H., Nikos, C., Christos, T., Sotiris, I., Konstantinos, F., Giorgos, D., and Marios, P. 2019. The CE-IoT Framework for Green ICT Organizations. ISSN. 2325-2944/19.

[34] Jayshree, G. A., and Dr. Akhil K. 2015. Green Solution (GS): A New Initiative For Energy-Efficient Computing Where Humans And Machines Work Together. International Conference on Energy Systems and Applications.

[35] Shalabh, A., Rana, B., and Asoke, N. 2014. Virtual Desktop Infrastructure in Higher Education Institution: Energy Efficiency as an application of Green Computing. Fourth International Conference on Communication Systems and Network Technologies. 978-1-4799-3070$8 / 14$

[36] Biswajit, S. 2014. Green Computing. International Journal of Computer Trends and Technology (IJCTT). vol. 14.

[37] Qayoom, and Insha. 2017. Minimization of Energy Consumption in Cloud Using Green Computing. International Journal of Advanced Research in Computer Science. Vol: 8 Issue 2. pp:40-42. 3p

[38] Iqbal, A., Hiroshi, O., and Kohei, A. 2015. Analysis on Existing Basic SLAs and Green SLAs to Define New Sustainable Green SLA. (IJACSA) International Journal of Advanced Computer Science and Applications. Vol. 6.

[39] Vimal, P. P., Apurva, K. P., and Dr. CK Kumbha Vimal P.Parmar, Apurva K. Pandya and Dr. CK Kumbharana. 2014. Optimization of Energy Usage for Computer Systems by Effective Implementation of Green Computing. International Journal of Advanced Networking Applications (IJANA). ISSN. 0975-0290.

[40] Allison, W., Jay, H., and Sally, A. 2008. A Bright Green Perspective on Sustainable Choices. CHI 2008 Proceedings. 
[41] S. Divya, M. 2016. Green Computing Turns Green IT. International Journal of Advance Research in Computer Science and Management Studie. vol.4. Issue 2. ISSN. 2321-7782.

[42] Renu, B., and Er. Jasdeep, M. 2017. A Research Paper on Green Computing Using Energy Efficient Task Allocation Strategy in Cloud Environment. International Journals of Advanced Research in Computer Science and Software Engineering. Vol. 7. Issue. 6. ISSN. 2277-128X

[43] Laura, D. R. 2016. Determinants of Green ICT Adoption in Organizations: A Theoretical Perspective.

[44] Muhammad, S., and Siffat, U. K. 2016. Developing Green and Sustainable Software: Success Factors for Vendors. 978-1-4673-9904-3/16.

[45] P. Jayarajan, S. Thenmozhi, R. Maheswar, S. Malathy, and R. Udaiyakumar. 2018. Smart Cloud Enabled EWaste Management System. International Conference on Computer Communication and Informatics. 978-1-53862238-4/18.

[46] Ayesha, A., and Anjum, S. 2013. Green Computing: Ewaste management through recycling. International Journal of Scientific \& Engineering Research. vol. 4, Issue. 5. ISSN. 2229-5518.

[47] Biswajit, D., Rayan, K., Rahul, B., and Sadhan, K. G. 2015. E-Waste Recycling as Criteria for Green Computing Approach: Analysis by QFD Tool. Chapter in Lecture Notes in Electrical Engineering.

[48] Biswajit, S. 2018. Green Computing: Current Research Trends. International Journal of Computer Sciences and Engineering. Vol. 6. Issue. 3. ISSN. 2347-2693.

[49] Brett, H. R. 2009. E-waste: An assessment for global production and environmental impact. Science of the Total Environment.
[50] Li, J., and Zhang, S. 2010. Study e-waste management based on EPR system. International Conference on EBusiness and E-Government. 978-0-7695-3997-3/10.

[51] Mr.N.P.Jadhav, Mr. R.S. Kamble, and Mr.S.V.Kamble. 2015. Green Computing-New Approaches of Energy Conservation and E-Waste Minimization. IOSR Journal of Computer Engineering (IOSR-JCE). ISSN. 22780661. ISBN. 2278-8727. pp. 25-29.

[52] Nikhita, M., Pooja, S., and Sudarshan, S. 2014. Green Technology for avoiding E-waste with the help of GIS. International Conference on Advances in Communication and Computing Technologies. 978-14799-7319-4/14.

[53] S. Vijaykumar, K. S. Rajkarthick, and P. Karthik. 2011 Green Techniques Between Birth And Death of Your PC. 978-1-4673-0178-7/11./

[54] Sania, K., Abdul, R. H., and Mohammed, S. A. K. 2015. Development of a Research Framework for Green IT Enablers using Interpretive Structural Modelling. International Journal of Green Computing (IJGC) 6(1).

[55] Sidra, A., Mahjabeen, G., Fatima, R., and Bushra, B. 2018. E-waste Reduction via Virtualization in Green Computing. American Scientific Research Journal for Engineering, Technology, and Sciences (ASRJETS). Vol. 41. No. 1. pp. 1-11. ISSN. 2313-4402.

[56] Stefanos, Th. T., Apostolos, I. K., and Angelos, G. C. 2014. Legislation, design, and management of the electrical and electronic waste (e-waste) procedures.

[57] Dr. Pranav, P. 2016. A Study of Approach to Green Computing: E-waste Management. International Journal of Computer Science and Mobile Applications. vol.4. pp. $1-6$. 